\title{
PERENNIAL LEGUMES AND GRASSES STABLE SOURCE OF QUALITY LIVESTOCK FODDER FEED
}

\author{
Z. Tomić ${ }^{1 *}, Z$ Lugić $^{2}$, J. Radović$^{2}$, D. Sokolović ${ }^{2}, Z$ Nešić ${ }^{1}$, \\ V. Krnjaja ${ }^{1}$ \\ ${ }^{1}$ Institute for Animal Husbandry, Belgrade-Zemun, Serbia \\ ${ }^{2}$ Institute for Forage Crops, Kruševac, Serbia \\ *Corresponding author: \\ e-mal: zotom@mail.com \\ **Plenary invited paper. Research financed by the Ministry of Science of Republic of Serbia. \\ Project TR 6872
}

\begin{abstract}
Perennial legumes, alfalfa, red clover, bird's foot trefoil, white clover, sainfoin and grasses, cock's foot, meadow fescue, tall fescue, Italian ryegrass, English ryegrass, French ryegrass, red fescue and Timothy grass can be grown successfully in pure crops and in legume-grass mixtures, on different soil types. Their importance in livestock development is based primarily on the great potential for yield of dry matter of over $20 \mathrm{t} \mathrm{ha}^{-1}$ if adequate agro-technical measures have been applied. Also, perennial legumes are characterized with high content of nutritive substances, especially protein and represent the most important protein source in livestock nutrition. Depending on the species and pheno stage of utilization, the content of crude proteins in grasses varies from 100 to $174,6 \mathrm{~g} \mathrm{~kg}^{-1}$ of $\mathrm{DM}$, and in perennial legumes from 190,0 to $228,8 \mathrm{~g} \mathrm{~kg}^{-1}$ of DM. Livestock feed obtained from these plant species can be used in several ways, from grazing as most efficient and economical way, to preparation of hay and high quality silages and haylages. Stated forage species are very important in sustainable agriculture and organic production, considering that they carry out the process of biological fixation of nitrogen, but also from the ecological aspect. By using diverse selection/breeding material numerous domestic cultivars of perennial legumes and grasses have been created which are characterized with high potential for main agronomical traits.
\end{abstract}

Key words: livestock fodder feed, quality, yield, legumes, grasses. 


\section{Introduction}

Main prerequisite for livestock development and increase of economical effects in production of meat and milk, in low land as well as hillymountainous regions, is cheap and high quality livestock fodder. In total cost of final livestock products livestock feed participates with 50-70\%. If the fact is considered that method of nutrition influences the health condition of domestic animals and duration of their exploitation, it is clear that fodder livestock feed represents the basis of success and development of livestock production. These species can be grown in pure crop or in combination with other species, which increases the economical efficiency of the production and at the same time enables production of food of higher nutritive value and digestibility. Perennial character considerably reduces the scope of agrotechnical operations which has positive effect on increase of economical efficiency of production.

Perennial legumes in Serbia are grown in pure crop on over 350.000 ha. Economically the most important and most present are alfalfa (Medicago sativa L.), red clover (Trifolium pratense L.), bird's foot trefoil (Lotus corniculatus L.) and white clover (Trifolium repens L.), although in the last decade sainfoin (Onobrychis viciifolia L.) and Swedish clover (Trifolium hybridum L.) became very important. Their economical significance is based on high potential for production of biomass (over $80 \mathrm{t} \mathrm{ha}^{-1}$ of green and close to $20 \mathrm{t} \mathrm{ha}^{-1}$ of dry matter) with high content of crude protein in biomass. Depending on the species and exploitation stage, content of crude protein is up to $24 \%$, whereas the yield of protein can be over $3.5 \mathrm{t} \mathrm{ha}^{-1}$ (Radović et al., 2007). Biomass is characterized with high content of macro and micro elements which can compensate their shortage in other species grown in the mixture (Ignjatović et al., 2001, Marković et al., 2007). Therefore, presence of perennial legumes in nutrition of domestic animals can considerably reduce, and in some cases even completely exclude, the use of concentrated protein feeds.

Process of biological nitrogen fixation gives to perennial legumes, not only from the economical, but also ecological aspect high significance and unavoidable role in sustainable and organic agricultural production. The level of biological nitrogen fixation is under significant influence of genotype, strain of bacteria - nitrogen fixator and factors of the environment. Correct choice of species in regard to altitude, edaphic and climatic conditions and their combination with perennial grasses it is possible to provide high quality fodder for livestock nutrition. Alfalfa is mainly grown 
in low land regions on soils of neutral to slight acid reaction, red clover can be grown in hilly-mountainous regions on soils of poorer quality and slightly higher acidity. Bird's foot trefoil can be grown in pure crop or mixture with perennial grasses, even on very acid soils.

Perennial grasses include all species widely spread, adaptable to different agro-ecological conditions which significantly increase their importance from the aspect of agronomy, especially on natural or artificial grasslands on higher altitudes. Numerous species of perennial grasses are cenobionts, i.e. builders of numerous natural plant associations of natural grasslands which take vast areas of Serbia (Stošić, 2005).

Perennial grasses represent basis of sustainable livestock production, as main feed for ruminants in the regions of moderate climate as component of natural or artificial/sown pastures (Stošić et al., 2005; Lazarević, et al., 1999), natural and artificial/sown meadows (Lazarević et al., 2001) which can be exploited either buy cutting (Stošić and Radojević, 1980), or for preparation of haylage and silage (Dinić et al., 2003). By rational management of perennial grass crops low prices of fodder livestock feed are achieved, considerably lower than concentrated feeds. The most important species for livestock nutrition are cock's foot (Dactylis glomerata L.), English ryegrass (Lolium perenne L.), meadow fescue (Festuca pratensis Huds.), tall fescue (Festuca arundinacea Schreb.), Timothy grass (Phleum pratense L.), Italian ryegrass (Lolium multiflorum Lam.), French ryegrass (Arrhenatherum elatius (L., P. Beauv. ex J. Presl\&C.Presl.), red fescue (Festuca rubra L.) and smooth brome (Bromus inermis Leyss).

\section{Production of fodder in low land region}

Low land region in Serbia includes Pannonian low land and considerable surfaces of agricultural land in river valleys, ravines and slight elevations/hills up to $200 \mathrm{~m}$ above sea level. The most present types of soil in these regions are chernozem, alluvial soils, smonitsa and in some regions also black soil, which are characterized with greater depth, fertility and neutral to poor acid reaction. On these surfaces, beside dominant presence of crop, vegetable and industrial cultures, considerable surfaces are used for growing alfalfa, red clover and various mixtures of perennial grasses and legumes. Choice of plant species or combination of several depends, primarily, on characteristics of soil at disposal and livestock breeding method. Perennial legumes and grasses in these regions provide high quality livestock feed exclusively for livestock breeding in stables. However, role of 
these species in composition of legume-grass mixtures which provide also possibility of grazing is extremely important as the most efficient from economical and health aspect, as the best method of livestock nutrition.

In low land region alfalfa has the greatest importance. Thanks to well developed and deep root system it can endure dry conditions and even in years with very low precipitation it realizes satisfactory yields. In years of full exploitation, alfalfa in four to five cuts realizes high yields of green mass $70-90 \mathrm{t} \mathrm{ha}^{-1}$ and up to $20 \mathrm{t} \mathrm{ha}^{-1}$ of dry matter, Radović et al., (2007). Choice of cultivar which is adapted to agro-ecological conditions provides high and stable yields during entire exploitation period. Domestic cultivars are better yielding than foreign, since they were created for these growing conditions, Radović et al., (2004).

Table 1. Plant height (cm), green and dry matter yield $\left(\mathrm{t} \mathrm{ha}^{-1}\right)$ and quality of forage perennial legume cultivars

\begin{tabular}{|c|c|c|c|c|c|c|c|}
\hline \multirow{2}{*}{ Species } & \multirow{2}{*}{ Cultivar } & \multirow{2}{*}{$\begin{array}{l}\text { Height } \\
(\mathrm{cm})\end{array}$} & \multicolumn{2}{|c|}{ Yield $\left(\mathrm{t} \mathrm{ha}^{-1}\right)$} & \multicolumn{3}{|c|}{ In $\mathrm{g} \mathrm{kg}^{-1}$ of $\mathrm{DM}$} \\
\hline & & & $\begin{array}{l}\text { ZK } \\
\text { GF }\end{array}$ & $\begin{array}{l}\mathrm{SM} \\
\mathrm{DM}\end{array}$ & $\begin{array}{l}\text { SP } \\
\text { CP }\end{array}$ & $\begin{array}{l}\mathrm{SC} \\
\mathrm{CC}\end{array}$ & $\begin{array}{l}\text { BEM } \\
\text { NFE }\end{array}$ \\
\hline \multirow{6}{*}{ Alfalfa } & K-1 & 60,0 & 57,8 & 13,6 & 223,5 & 230,0 & 427,5 \\
\hline & M-2 & 63,3 & 59,3 & 14,1 & 228,7 & 239,1 & 403,0 \\
\hline & K-22 & 69,0 & 76,7 & 17,6 & 163,1 & 326,0 & 415,0 \\
\hline & K-23 & 78,0 & 64,3 & 14,9 & 162,2 & 279,9 & 399,2 \\
\hline & K-28 & 74,6 & 71,2 & 16,5 & 201,1 & 264,3 & 398,2 \\
\hline & K-42 & 68,6 & 70,8 & 16,2 & 223,8 & 262,2 & 389,4 \\
\hline \multirow{7}{*}{ Red clover } & $\mathrm{K}-3$ & 69,2 & 51,3 & 9,9 & 183,5 & 213,2 & 425,1 \\
\hline & K-17 & 62,4 & 53,1 & 11,7 & 199,5 & 194,5 & 411,2 \\
\hline & K-9 & 58,4 & 52,3 & 11,5 & 210,1 & 221,6 & 436,3 \\
\hline & $\mathrm{K}-27$ & 73,3 & 55,4 & 12,2 & 190,6 & 304,1 & 445,7 \\
\hline & K-32 & 86,7 & 53,2 & 11,7 & 198,0 & 232,9 & 462,3 \\
\hline & K-38 & 76,3 & 55,9 & 12,3 & 205,3 & 190,1 & 412,8 \\
\hline & K-39 & 78,0 & 54,5 & 12,0 & 210,4 & 194,6 & 441.2 \\
\hline \multirow[t]{2}{*}{ Birds foot trefoil } & Šumadija & 38,6 & 63,1 & 12,6 & 198,0 & 326,2 & 335,1 \\
\hline & $\mathrm{K}-37$ & 39,5 & 69,4 & 13,2 & 210,2 & 301,3 & 344,2 \\
\hline White clover & K-33 & 27,2 & 52,0 & 9,9 & 186,1 & 210,2 & 423,1 \\
\hline Sainfoin & Krajina & 74,7 & 49,9 & 11,7 & 182,8 & 270,5 & 445,2 \\
\hline
\end{tabular}

*Results of the Committee for cultivar acknowledgment

Alfalfa is mainly grown as pure crop, although it realizes satisfactory results even when grown in mixture with grasses (Nešić et. al., 2007). 
It is used for livestock nutrition in different forms, most frequently as hay, but also dried/dehydrated in form of briquettes, as silage, haylage or for grazing. Alfalfa hay is rich in proteins of excellent amino-acid composition and high digestibility. Proteins from alfalfa hay are the cheapest protein source in livestock feed.

Red clover is the second most important perennial legume in our country and it is grown in pure crop on approx. 120.000 ha. In poor conditions, without application of modern agro-technical measures it realizes yields of approx. $4 \mathrm{t} \mathrm{ha}^{-1}$ of dry matter. When modern agro-technical measures are applied and in favourable agro-ecological conditions it realizes extremely high yields in the second year of exploitation.

Red clover is characterized with good quality, high content of crude protein which in blooming stage and depending on the cultivar varies from 186,4 to $226,4 \mathrm{~g} \mathrm{~kg}^{-1} \mathrm{SM}$, Lugić et al. (2002), Lugić et al.(2006). Usual method of exploitation of this species is preparation of hay but this is usually associated with high losses of nutritive substances. By application of adequate preservation methods and procedures of fermentation stimulation, biomass of red clover can successfully be ensiled, which would considerably reduce the losses of nutritive substances and enable its use throughout the year, Dinić et al., (1994).

Quality of the forage of perennial legumes depends greatly on development phase (tab.2). Although the amounts of N, P, Ca and K decrease in later development stages, even in these latest stages the amounts of stated macro elements satisfy the needs of cattle and dairy cows, as well as in all micro elements (except $\mathrm{Zn}$ ).

In low land regions, on less suitable soils, grass-legume mixtures are grown. Choice of species for mixtures is based on biological characteristics of species, adaptability to certain climatic and edaphic conditions, and exploitation method.

For growing in lowland terrains, the most suitable species are Italian ryegrass, meadow and tall fescue and cock's foot with many registered cultivars, in pure crops or in mixture with perennial legumes, Lazarević et al., (2001).

In Serbia so far, numerous cultivars of perennial grasses were created which can be components of mixtures for low land regions, such as: cook's foot K-6, K-7, K-rana and K-40, Italian ryegrass K-13 and K-29t, meadow fescue K-21, tall fescue K-19, K-20 and NS 10 and the latest acknowledged cultivar of English ryegrass K-11. All these cultivars for production of livestock feed are characterized with high genetic potential for production of 
biomass, i.e. dry matter of good quality, as well as specific traits such as various maturation periods, increased persistence and resistance to stressful environment conditions, primarily drought (tab. 3).

Table 2. Macro elements and trace elements contents in different growth stages of alfalfa, red and white clover ( $\left.\mathrm{gkg}^{-1} \mathrm{DM}\right)$ (Ignjatović et al., 2001, Marković et al., 2007)

\begin{tabular}{|c|c|c|c|c|c|c|c|c|c|c|}
\hline \multirow[t]{2}{*}{ Species } & \multirow[t]{2}{*}{ Phase } & \multicolumn{5}{|c|}{ Macro elements } & \multicolumn{4}{|c|}{ Trace elements } \\
\hline & & $\mathrm{N}$ & $P$ & $\mathrm{~K}$ & $\mathrm{Ca}$ & $\mathrm{Mg}$ & $\mathrm{Fe}$ & $\mathrm{Zn}$ & $\mathrm{Cu}$ & $\mathrm{Mn}$ \\
\hline \multirow{4}{*}{ Alfalfa } & $\mathrm{I}$ & 40,5 & 2,9 & 22,1 & 24,8 & 3,0 & 221,3 & 36,0 & 27.5 & 51,2 \\
\hline & II & 35,2 & 3,0 & 21,4 & 18,0 & 2,8 & 215,2 & 21,4 & 14,9 & 39,4 \\
\hline & III & 31,4 & 2,7 & 18,3 & 14,0 & 2,7 & 143,4 & 17,7 & 14,6 & 48,2 \\
\hline & $\begin{array}{c}\text { Lsd } \\
0,01\end{array}$ & 0,48 & 0,43 & 1,54 & 1,55 & 0,33 & 6,213 & 1,364 & 1,592 & 1,592 \\
\hline \multirow{4}{*}{$\begin{array}{c}\text { Red } \\
\text { clover }\end{array}$} & I & 47,4 & 4,7 & 22,9 & 25,9 & 9,7 & 249,0 & 33,5 & 38,4 & 66,5 \\
\hline & II & 39,1 & 4,1 & 21,6 & 25,4 & 8,4 & 144,8 & 31,4 & 40,1 & 76,4 \\
\hline & III & 31,5 & 3,3 & 17,5 & 23,6 & 7,6 & 146,8 & 22,4 & 35,4 & 62,8 \\
\hline & $\begin{array}{l}\text { Lsd } \\
0,01\end{array}$ & 6,50 & 0,30 & 0,80 & 1,10 & 1,00 & 7,666 & 2,133 & 1,802 & 3,108 \\
\hline \multirow{4}{*}{$\begin{array}{l}\text { White } \\
\text { clover }\end{array}$} & I & 47,6 & 5,2 & 20,2 & 21,5 & 8,0 & 374,7 & 45,7 & 13,1 & 68,6 \\
\hline & II & 42,6 & 4,2 & 20,5 & 22,2 & 8,5 & 238,3 & 40,7 & 15,0 & 62,0 \\
\hline & III & 33,4 & 3,5 & 15,3 & 17,9 & 6,8 & 209,8 & 38,5 & 11,6 & 48,1 \\
\hline & $\begin{array}{c}\text { Lsd } \\
0,01 \\
\end{array}$ & 1,80 & 0,20 & 2,10 & 1,00 & 1,00 & 26,0 & 4,10 & 1,90 & 7,40 \\
\hline
\end{tabular}

Table 3. Stem height $(\mathrm{cm})$, yield $\left(\mathrm{t} \mathrm{ha}^{-1}\right)$ of dry matter (DM) and quality of cultivars of perennial grasses acknowledged since 1979

\begin{tabular}{|c|c|c|c|c|c|}
\hline \multirow{3}{*}{ Species } & \multirow{2}{*}{ Cultivar } & \multirow{2}{*}{$\begin{array}{c}\text { Height } \\
(\mathrm{cm})\end{array}$} & $\begin{array}{c}\text { Dry matter } \\
\text { yield } \\
\left(\mathrm{t} \mathrm{ha}^{-1}\right)\end{array}$ & \multicolumn{2}{|c|}{$\mathrm{In} \mathrm{k} \mathrm{kg}^{-1}$ of DM } \\
\cline { 4 - 6 } & & & $\mathrm{CP}$ & $\mathrm{CF}$ \\
\hline \multirow{3}{*}{ Cock's foot } & $\mathrm{K}-6$ & 105 & $11,6-13,4$ & $132-175$ & $250-285$ \\
\cline { 3 - 6 } & $\mathrm{K}-7$ & 116 & $8,9-10,1$ & $125,2-164,9$ & 250 \\
\cline { 2 - 6 } & $\mathrm{K}-\mathrm{rana}$ & $89,3-120$ & $9,12-10,44$ & $84-127,8$ & $297-313,1$ \\
\cline { 2 - 6 } & $\mathrm{K}-40$ & 86,6 & 10,59 & $103,6-170,6$ & 272,3 \\
\hline \multirow{2}{*}{ Timothy grass } & $\mathrm{K}-15$ & 56,3 & $7,5-13,11$ & $83,6-113,3$ & $268,2-293,6$ \\
\cline { 2 - 6 } & $\mathrm{K}-41$ & 86,6 & 6,56 & 139,5 & 270 \\
\hline \multirow{2}{*}{ Italian ryegrass } & $\mathrm{K}-13$ & $59,7-67$ & $10,36-14,07$ & $115,7-142,6$ & $219,2-252,2$ \\
\cline { 2 - 6 } & $\mathrm{K}-29 \mathrm{t}$ & 65,7 & 15,5 & 145,7 & 234 \\
\hline Meadow fescue & $\mathrm{K}-21$ & 80 & $12-13,5$ & $124,8-132,4$ & $225-290,7$ \\
\hline \multirow{3}{*}{ Tall fescue } & $\mathrm{K}-19$ & 97,5 & $13,3-17,72$ & $113,4-118$ & 304,6 \\
\cline { 2 - 6 } & $\mathrm{K}-20$ & 95 & $13,15-15,66$ & 102,6 & 269,8 \\
\cline { 2 - 6 } & $\mathrm{NS}-10$ & 100 & 12,11 & 115 & 271 \\
\hline Red fescue & $\mathrm{K}-14$ & 64,3 & $7,01-10,56$ & 117,7 & 265,4 \\
\hline French ryegrass & $\mathrm{K}-12$ & 66 & $8,23-12,46$ & 132,4 & 318,0 \\
\hline English ryegrass & $\mathrm{K}-11$ & 42,2 & 7,25 & $97-134$ & 307,2 \\
\hline
\end{tabular}


Italian ryegrass is typical low land perennial grass species suitable for sowing in pure crop or in mixture with red clover, and in domestic assortment of cultivars it has two. Diploid cultivar K-13 is characterized with average three year yield of dry matter of $14,07 \mathrm{tha}^{-1}$ and yield of crude proteins of $1646 \mathrm{~kg} \mathrm{ha}^{-1}$ (Tomić and Popović, 1996). Cultivar K-29t is the first autotetraploid cultivar of perennial grasses in Serbia obtained artificially by induction of polyploidy, and it realizes average three year yield of dry matter of $15,5 \mathrm{t} \mathrm{ha}^{-1}$ and yield of proteins of $2328 \mathrm{~kg} \mathrm{ha}^{-1}$ (Tomić et al., 2001).

Cock's foot is one of the most important perennial grasses. It is very competitive and suitable for growing in mixture with (Nešić, 2006). In assortment of domestic cultivars it is presented with 4 cultivars which can be used in low land and high land regions on altitudes over $1000 \mathrm{~m}$. Cultivars K-6 and K-7 were among the first created cultivars in Serbia. Cultivar K-6 is high productive with average three year yield of dry matter of $13,4 \mathrm{t} \mathrm{ha}^{-1}$ and average of 13,2\% of crude proteins (Tešić-Jovanović et al., 1978, Tomić et al., 1992), whereas the cultivar K-7 in three year investigation in low land region realized yield of dry matter of $8,9 \mathrm{t} \mathrm{ha}^{-1}$ (Čolić et al., 1982). Four year average of dry matter yield of cultivar K-6 was $11,6 \mathrm{t} \mathrm{ha}^{-1}$, whereas the cultivar K-7 as late maturing species reached 10,1 t ha ${ }^{-1}$ (Mijatović, 1978). By investigating the chemical composition of dry matter of this cultivar, the same author established that content of crude protein in four cuts of cultivar $\mathrm{K}-6$ was from 175 to $203,4 \mathrm{~g} \mathrm{~kg}^{-1}$, i.e. from 164,9 to $179,8 \mathrm{~g} \mathrm{~kg}^{-1}$ in cultivar $\mathrm{K}-7$. Content of crude fibre in both cultivars was approx. $250 \mathrm{~g} \mathrm{~kg}^{-1}$. Cultivar K-rana/early was created as early maturing synthetic cultivar and it is characterized with high yield of dry matter of approx. $10 \mathrm{t} \mathrm{ha}^{-1}$ (tab.3) which is higher than yield of foreign cock's foot cultivars in local ecological conditions (Sokolović et al., 2004). New cock's foot cultivar K-40 was created from 7 autochthonous populations, it is resistant to low temperatures and flattening. It realizes in average approx. 10,5 $\mathrm{t} \mathrm{ha}^{-1}$ of dry matter annually (Tomić et al., 2001a; Sokolović et al., 2004) with $164,3 \mathrm{~g} \mathrm{~kg}^{-1}$ of crude protein.

Meadow fescue cultivar K-21 is very productive cultivar (Tomic and Tešić-Jovanović, 1986). It has high quality of dry matter with average 124,8 $\mathrm{g} \mathrm{kg}^{-1}$ of crude protein and $290,7 \mathrm{~g} \mathrm{~kg}^{-1}$ of crude fibre (Ignjatović et al., 2004), whereas tall fescue cultivars K-19 and K-20 are high yielding cultivars with over $13 \mathrm{t} \mathrm{ha}^{-1}$ of dry matter (Krstić et al., 1982) improved leaf presence and quality. Tall fescue also is species with extraordinary adaptability to agro-ecological growing conditions. 
English ryegrass is main component of mixtures for grazing, but also for cutting, in low land and hilly regions. The latest cultivar of perennial grasses in domestic assortment is K-11, medium maturation synthetic cultivar of English ryegrass which has increased tolerance to dry conditions of the environment. It is characterized by average yield of dry matter of $6,45 \mathrm{tha}^{-1}$, which in year 2006, on locations in Kruševac and Zaječar was 8,22 and 8,65 $\mathrm{t} \mathrm{ha}{ }^{-1}$, respectively (Sokolović et al., 2007). Content of crude proteins was $115,5 \mathrm{~g} \mathrm{~kg}^{-1}$ dry matter, and crude fibre $307,2 \mathrm{~g} \mathrm{~kg}^{-1}$. Average height of the plant was $42,2 \mathrm{~cm}$.

\section{Production of fodder in hilly-mountainous regions}

On high land terrains in Serbia soils are predominantly shallow and poor in regard to main nutritive elements, very often of low $\mathrm{pH}$ value. Average temperatures are considerably lower and in the winter there is thick snow cover and different distribution of precipitation during the year. In such regions it is impossible to grow alfalfa and red clover, therefore white clover, bird's foot trefoil and sainfoin are used.

White clover is leading forage legume in Great Britain and New Zealand, and in our country it is rarely used as component for establishing of artificial grasslands. Possibilities for growing of this species, especially in more humid, hilly-mountainous regions are not close to being exploited, in spite of its high potential for yield of high quality biomass and rich gene resources/fund of this species in wild flora (Krstić and Lugić, 1996; Lugić et al. 1996). From 2-3 cuts during one year in dry crop production, dry matter yields of 10-12 $\mathrm{t} \mathrm{ha}^{-1}$ of high nutritive value are realized (tab. 1). Beside its importance in production of livestock feed, this species can be used for composing mixtures for decorative green spaces/areas and as meliferous plant.

Bird's foot trefoil is grown in pure crop and in legume-grass mixtures and it is mainly used for preparation of hay, as well as grazing since it doesn't cause the bloat in ruminants. Depending on the edaphic and climatic conditions it is cut 2-4 times and yields 35-40 $\mathrm{t} \mathrm{ha}^{-1}$ of green mass, i.e. 8-10 $\mathrm{t}$ $\mathrm{ha}^{-1}$ of dry mass. Content of crude proteins depends on the cultivar and varies from 198 to $234 \mathrm{~g} \mathrm{~kg}^{-1} \mathrm{DM}$, and yield of protein from 0,78 to $1,2 \mathrm{tha}^{-1}$ (Radović et al., 2003).

Sainfoin is perennial forage legume grown in Serbia moderately, although it is present in some parts on natural meadows. It grows well in arid conditions, on light, carbonate soils, where from 2-3 cuts during 
vegetation it can give 30-60 $\mathrm{t} \mathrm{ha}^{-1}$ of green mass, i.e. 7,5-14 $\mathrm{t} \mathrm{ha}^{-1}$ of dry matter (Stanisavljević et al. 2004). It can be grown in pure crop or in legume-grass mixtures. It gives hay of high quality if cut before formation of buds.

Grass species adapted to hilly-mountainous conditions of growing are first of all Timothy grass, red fescue and French ryegrass. But, also cock's foot, meadow and tall fescue can also be used in mixtures for hillymountainous regions.

Domestic assortment of these perennial grass species is also very rich. Cultivars of Timothy grass K-15, as well as red fescue K-14 and French ryegrass K-12 are the first domestic cultivars. Timothy grass K-15 on mountain locations realizes hay yield of $7,5 \mathrm{t} \mathrm{ha}^{-1}$ (Tomić et al., 1997) to 13,11 $\mathrm{t} \mathrm{ha}^{-1}$ (Tomić et al., 1989). New cultivar of Timothy grass K-41, Tomić, (2002,), so far in trials and due to unfavourable climatic conditions, realized relatively lower yield $\left(6,56 \mathrm{t} \mathrm{ha}^{-1}\right)$ compared to previous yield of $\mathrm{K}$ 15 , but this yield was higher than yield of foreign cultivar Foka $\left(6,25 \mathrm{t} \mathrm{ha}^{-1}\right)$ (Sokolović et al., 2004). Cultivar of red fescue K-14 realized yield of dry matter of $10,56 \mathrm{t} \mathrm{ha}^{-1}$, whereas in later investigations it realized between $7,095 \mathrm{t} \mathrm{ha}^{-1}$ (Tomić et al., 1998) and 7,82 $\mathrm{t} \mathrm{ha}^{-1}$ (Sokolović et al., (2004) which was higher than the yield of foreign cultivar $\operatorname{Kos}\left(7,69 \mathrm{t} \mathrm{ha}^{-1}\right)$. Tomic et al., (2002a, 2007) stated that cultivar K-12 realized yield of dry matter of approx. $12,5 \mathrm{t} \mathrm{ha}^{-1}$ with approx. $130 \mathrm{~g} \mathrm{~kg}^{-1}$ of crude protein.

\section{Grass-legume mixtures}

For production of high quality fodder in different cultivation and exploitation conditions, perennial grasses are mainly sown in mixtures with perennial legumes. By combination of more grass and legume species the vegetation space is more complete and economical efficiency of exploitation on soils which are not suitable for growing alfalfa is increased. Due to high sugar content some perennial grasses are very suitable for ensiling. In accordance with needs of producers and characteristics of soil, grass-legume mixtures are composed for certain regions.

Mixtures are composed for different purposes, cutting, grazing and ensiling. The most present mixtures for grazing in low land regions are mixtures of white clover and English ryegrass, as well as other grass species. Also, very much present in low land region is mixture of red clover and Italian ryegrass, which is considered as short term exploitation mixture for cutting and ensiling (Tomić et al. 2001). Also, polyvalent mixtures of alfalfa 
and several grass species are used, cock's foot is the most used grass species for this purpose (Lazarević et al. 1999, Nešić et. al., 2007). For hillymountainous terrains most often bird's foot trefoil, red and white clover, legume components and cock's foot, Timothy grass, meadow fescue, red fescue, French ryegrass and grass components are used (Lazarević et al. 2001, Stošić, 2005).

\title{
Conclusion
}

Due to their biological traits of perennial legumes and grasses are very important forage species, from the economical and ecological aspect. They can be grown successfully in different agro-ecological conditions, from low land to mountainous regions of Serbia.

Potential for yield of domestic cultivars of perennial legumes is up to 20 $\mathrm{tha}^{-1} \mathrm{DM}$, and in perennial grasses, depending on the species 7-17 tha $\mathrm{hM}^{-1} \mathrm{DM}$

Perennial legumes are characterized with high quality, especially content of crude proteins, which depending on the exploitation stage is up to $230 \mathrm{~g}$ $\mathrm{kg}^{-1} \mathrm{DM}$.

Biomass of perennial legumes is characterized with high content of macro and micro elements which can compensate their shortage in other species grown in the mixture.

Perennial legumes and grasses are unavoidable factor of successful livestock production, in low land and hilly-mountainous regions.

\section{VIŠEGODIŠNJE LEGUMINOZE I TRAVE - STABILAN IZVOR KVALITETNE KABASTE STOČNE HRANE}

\author{
Z. Tomić, Z Lugić, J Radović, D Sokolović, Z Nešić, V. Krnjaja
}

\section{Rezime}

Višegodišnje leguminoze, lucerka, crvena detelina, žuti zvezdan, bela detelina, esparzeta i trave ježevica, livadski vijuk, visoki vijuk, italijanski ljulj, engleski ljulj, francuski ljulj, crveni vijuk i mačiji rep, mogu se uspešno gajiti u čistom usevu ili u leguminozno-travnim smešama, na različitim tipovima zemljišta. Njihov značaj u razvoju stočarstva, pre svega, 
se zasniva na visokom potencijalu za prinos suve materije, koji se uz primenu savremenih agrotehničkih mera kreće i preko $20 \mathrm{t} \mathrm{ha}^{-1}$. Pored toga, višegodišnje leguminoze se odlikuju visokim sadržajem hranljivih materija, posebno proteina i predstavljaju najvažniji izvor proteina u ishrani domaćih životinja. U zavisnosti od vrste i fenofaze iskorišćavanja sadržaj sirovih proteina kod trava se kreće od 100 do $174,6 \mathrm{~g} \mathrm{~kg}^{-1} \mathrm{SM}$, a kod višegodišnjih leguminoza od 190,0 do 228,8 $\mathrm{g} \mathrm{kg}^{-1} \mathrm{SM}$. Stočna hrana dobijena od ovih biljnih vrsta može se koristiti na više načina, od ispaše kao najefikasnijeg i najekonomičnijeg načina, preko pripreme sena, do spravljanja kvalitetnih senaža i silaža. Navedene krmne vrste imaju veoma značajno mesto u održivoj poljoprivredi i organskoj proizvodnji, obzirom da obavljaju proces biološke fiksacije azota, veoma su značajne i sa ekološkog aspekta. Korišćenjem divergentnog selekcionog materijala stvoren je veliki broj domaćih sorti višegodišnjih leguminoza i trava koje se odlikuju visokim potencijalom za osnovna agronomska svojstva.

\section{References}

ČOLIĆ D., OCOKOJIĆ S., VALENTA M. i ZBIGNJEV P.(1982): Prinosi suve nmaterije nekih sorata visokog vijuka, ježevice, francuskog ljulja, mačijeg repka i livadskog vijuka u nizijskom području SR Srbije, Sinopsisi referata IV jugoslovenskog simpozijuma o krmnom bilju, Novi Sad, 42-44.

DINIĆ B., LUGIĆ Z., STOŠIĆ M., RADOVIĆ J. (1994): Uticaj provenjavanja i nivoa kukuruzne prekrupe na kvalitet silaže crvene i bele deteline. Biotehnologija u stočarstvu, 10, 3-4, 71-80.

DINIĆ B., LAZAREVIĆ D., IGNJATOVIĆ S., DORDJEVIĆ N. (2003): The influence of development phase and dry matter level on quality and nutritive value of orchardgrass silage. Procceding of 11th International scientific Symposium "Forage Conservation", Nitra, Slovak Republic, 130131.

IGNJATOVIĆ S., VUČETIĆ J., LUGIĆ Z., DINIĆ B. (2001): Effect of growth stage on macro and trace elements content in red and white clover. Journal of Scientific Agricultural Research, 62, 220, 309-316.

IGNJATOVIĆ S., SOKOLOVIĆ D., JEVTIĆ G., VASIĆ T. (2004): Uticaj starenja na hemijski sastav višegodišnjih trava. Acta Ariculturae Serbica, IX, 17, 325-329.

KRSTIĆ O., TEŠIĆ-JOVANOVIĆ B., TOMIĆ Z., (1982): Osobine sorti visokog vijuka, Zbornik radova IV jugoslovenskog simpozijuma o krmnom bilju, Novi Sad, 84-96. 
KRSTIĆ O., LUGIĆ Z. (1996): Kruševačka 33 (K-33), nova sorta bele deteline (Trifolium repens L.) Zbornik radova Instituta za ratarstvo i povrtarstvo, 26, 71-75.

LAZAREVIĆ D., STOŠIĆ M., DINIĆ B., TERZIĆ D.(1999): Dynamics of grass-legume mixture production under continuous grazing by sheep. Biotehnologija u stočarstvu. 15. 3-4, 77-87.

LAZAREVIĆ D., STOŠIĆ M., DINIĆ B., LUGIĆ Z. (2001): Grass-legume mixture productivity under grazing and cutting utilization. Journal of mountain agriculture on the Balkans. .4, 1, 40-52.

LUGIĆ Z., STOŠIĆ M., MRFAT-VUKELIĆ S., RADOVIĆ J. (1996): Study of morphological features of the white clover (T. repens L.) from the wild flora in Serbia. Proceedings of the 16th EGF meeting Grassland and Land use systems, Grado-Italy, 781-785.

LUGIĆ Z., ZAPLETANOVA I, DINIĆ B., LAZAREVIĆ D. (2002): Investigation of agronomic important traits of diploid and tetraploid red clover (Trifolium pratense L.) cultivars in agro-ecological conditions of Serbia. Grassland Science in Europe. V1. 7. 84-85.

LUGIĆ Z., RADOVIĆ J., SOKOLOVIĆ D., JEVTIĆ G. (2006): Forage yield and quality of some new cultivar of red clover (Trifolium pratense L.) in Serbia. EUCARPIA Medicago spp. Group Meeting., Perugia, Italy, 122124.

MARKOVIĆ J., IGNJATOVIĆ S., RADOVIĆ J., LUGIĆ Z. (2007): Uticaj faze razvića na sadržaj makro i mikro elemenata u lucerki i crvenoj detelini. Zbornik radova, Institut za ratarstvo i povrtarstvo, Novi Sad, 44, 1, 401-406. MIJATOVIĆ M. (1978): Produktivnost i hranljiva vrednost nekih sorata Dactylis glomerata pri intenzivnom gajenju i iskorišćavanju. Sinopsisi III Jugoslovenskog simpozijuma o krmnom bilju, Bled, 177-180.

NEŠIĆ Z (2006): Uticaj đubrenja azotom i udela lucerke na prinos i kvalitet krme sejanog travnjaka. Magistarski rad. Poljoprivredni fakultet BeogradZemun, 1-100.

NEŠIĆ Z., TOMIĆ Z., VUČKOVIĆ S., RUŽIĆ-MUSLIĆ D. (2007): Prinos travno-leguminoznih smeša u zavisnosti od botaničkog sastava i djubrenja azotom. Zbornik radova XI simpozijuma o krmnom bilju sa medjunarodnim učešćem » Održivi sistemi proizvodnje i iskorišćavanja krmnog bilja«, Novi Sad, vol. 44, 375-379.

RADOVIĆ J., DINIĆ B., PUDLO V. (2003): Productivity and quality of some birdfoot trefoil (Lotus corniculatus L.) varieties. EGF, Pleven, Bulgaria, 8, 118-121.

RADOVIĆ J., LUGIĆ Z., IGNJATOVIĆ S., DELIĆ D. (2004): Prinos i 
kvalitet suve materije genotipova lucerke (Medicago sativa L.) različitog porekla. Acta Agriculturae Serbica, IX, 17 (2004), 9-657, 109-114. RADOVIĆ J., LUGIĆ Z., SOKOLOVIĆ D., ŠTRBANOVIĆ R., VASIĆ T. (2007): Kruševačka 42 (K-42), nova sorta lucerke (Medicago sativa L.). Zbornik radova, Institut za ratarstvo i povrtarstvo, Novi Sad, 44, 1, 143-149. STANISAVLJEVIĆ, R., MILENKOVIĆ, J., STOJANOVIĆ, I. (2004): Uticaj količine semena i međurednog rastojanja na prinos i kvalitet semena esparzete (Onobrychis sativa L.) Acta agriculture Serbica, 9, 17, 317-323.

SOKOLOVIĆ D., IGNJATOVIĆ S., TOMIČ Z. (2004): Prinos i kvalitet krme eksperimentalnih genotipova višegodišnjih trava. Acta Ariculturae Serbica, IX, 17, 135-142.

SOKOLOVIĆ D., LUGIĆ Z., RADOVIĆ J., TOMIĆ Z., BABIĆ S., VUČKOVIĆ M. (2007): Agronomska svojstva nove sorte engleskog ljulja Kruševački $11(\mathrm{~K}-11)$. Zbornik radova Instituta za ratarstvo i povrtarstvo Novi Sad, Vol. 44, 169-176.

STOŠIĆ, M., RADOJEVIĆ, D. (1980): Duration and suitability of grasslegume mixtures for forage production in the mountain regions of Serbia. EGF 8th General Meeting. 93-101.

STOŠIĆ M. (2005): Country Pasture/Forage Resource Profiles: Serbia and Montenegro,www.fao.org/ag/AGP/AGPC/doc/ounprof/serbiamontenegro/ser biamont. htm

STOŠIĆ M., LAZAREVIĆ D., DINIĆ B., TERZIĆ D., SIMIĆ A. (2005): Natural grasslands as basic of livestock development in hilly-mountainous regions of central Serbia. 8th International Symposium "Modern Trends in Livestock Production". Biotehnology in Animal Husbandry. 21, 1, 265-273. TEŠIĆ-JOVANOVIĆ B, KRSTIĆ O., OCOKOJIĆ S., ČOLIĆ D. (1978): Proučavanje produktivnosti nekih stranih i domaćih sorata ježevice (Dactylis glomerata L.) u uslovima Kruševca i Zlatibora, Sinopsisi III Jugoslovenskog simpozijuma o krmnom bilju, Bled, 161-164.

TOMIĆ Z., TEŠIĆ-JOVANOVIĆ B. (1986): Sorta livadskog vijuka "Kruševački 21", Festuca pratensis Huds, Rešenje Saveznog sekretarijata za poljoprivredu br. 481 od 15.01.1986. god.

TOMIĆ, Z., STOŠIĆ, M., ČOLIĆ D. (1989): The dry matter yield of grass cultivarss in the Upland of Sebia, Proc. XVI International Grassland Congress, Nice, France, 1455-1456.

TOMIĆ Z., POPOVIĆ J. (1996): Tetraploidna sorte italijanskog ljulja (Lolium multiflorum Lam.) KRUŠEVAČKI 29 tetra, Zbornik radova Instistuta za ratarstvo i povrtarstvo, sveska 26 , Novi Sad, 89-96. TOMIĆ Z., SOKOLOVIĆ D., OSTOJIĆ S. (1997): Fodder production of 
timothy (Phleum pratense L.) genotypes on mountain Kopaonik, Agricultural Science Journal of Mountain Agricuture on the Balkans, 1, 1, 47-55.

TOMIĆ Z., SOKOLOVIĆ D., IGNJATOVIĆ S., DINIĆ B. (1998): Dry matter production of red fescue (Festuca rubra L.) genotypes use under cutting and grazing management on Kopaonik mountain. Procc. of the 17th General Meeting of the European Grassland Federation, May 18-21, 1998, Debrecen, Hungary, 925-927.

TOMIĆ Z., KRSTIĆ O., MRFAT-VUKELIĆ S., (1992): Nova sorta ježevice, Dactylis glomerata L. "Kruševačka rana". Rešenje Saveznog komiteta za poljoprivredu, br.2/0-04-037/022 od 6.8.1992. godine. TOMIĆ Z., LUGIĆ Z., SOKOLOVIĆ D., IGNJATOVIĆ S. (2001): Production of Dry matter and Quality of grass, legumes and grasslegumes mixture, J. Sci. Agric. Research/Arhiv za poljoprivredne nauke, 62, 220, 259-266.

TOMIĆ Z., S. MRFAT-VUKELIĆ, Z. LUGIĆ, D. SOKOLOVIĆ I J. RADOVIĆ (2001a): Nova sorta ježevice Kruševačka 40 (K-40). Rešenje Saveznog ministrastva za poljoprivredu, Savezni zavod za biljne i životinjske genetičke resurse, br.4/008-186/058 od 14.07.2001.

TOMIĆ ZORICA (2002): Nova sorta krmnog bilja, Sorta mačiji rep K-41 (Kruševačka - 41), Savezni Zavod za bijne i životinjske genetičke resurse, br. 4/008-089/002, 18.02.2002.

TOMIĆ Z., SOKOLOVIĆ D., IGNJATOVIĆ S., ŽUJOVIĆ M., NEGOVANOVIĆ D, KRNJAJA V., NEŠIĆ Z., VORKAPIĆ M. (2002a): Chemical Composition of Domestic and Foreign Cultivars of Perennial Grasses According to Cuts For Animal. 15 ${ }^{\text {th }}$ Symposium on Innovation in Animal Science and Production. Biotehnology in Animal Husbandry, 18, 56, 251-256.

TOMIĆ Z., SOKOLOVIĆ D., RADOVIĆ J., NEŠIĆ Z., MARINKOV G. (2007): New Domestic cultivars of Perennial Grasses Used as Livestock Production. Biotehnology in Animal Husbandry, 23, 1-2, 81-87. 